\title{
SUBVERSIVE POWER OF THE SUPERNATURAL: ELEMENTS OF MAGIC REALISM IN A. CARTER'S NIGHTS AT THE CIRCUS AND G. E. ANSALDÚA'S BORDERLANDS LA
}

\section{FRONTERA: THE NEW MESTIZA}

Mirna Ćurić, Faculty of Philosophy, University of Novi Sad, mina mirnabijedicdc@gmail.com

DOI: 10.31902/fll.36.2021.8

\begin{abstract}
This paper focuses on elements of magic realism in Angela Carter's Nights at the Circus and Gloria E. Anzaldúa's Borderlands La Frontera: The New Mestiza. Though these two novels belong to different literary canons and its storylines refer to different time frames, the writers use mythical and supernatural elements for similar purposes - to undermine the impositions of dominant British and American societies. Both writers incorporate elements of magic into reality to challenge mainstream patriarchal and Western views of women, as well as justify and validate identities based on hybridity and difference.
\end{abstract}

Keywords: Magic realism, reality, supernatural, myth, gender, culture, hybridity Carter, Anzaldúa

\section{Introduction}

As debates over the exact definition of magic realism, its notions, forms, and representations vigorously continue (Bowers 1-6), this paper aims to look at elements of magic realism in Angela Carter's novel Nights at the Circus, published in 1984, and Gloria E. Anzaldúa's Borderlands La Frontera: The New Mestiza, published in 1987. Despite the proximity in publication, the novels' storylines refer to different eras, with Carter's work referencing the Victorian era and Anzaldúa's work referring to the twentieth century. Even though the two novels are part of different literary canons-British and American-and feature storylines set in different periods, both authors employ elements of magical realism to depict social, gender, and cultural issues in their respective societies at the time. The books also display a variety of literary genres. Nights at the Circus represents a piece of fiction that employs elements of magical realism and fantasy "as a means of presenting a feminist perspective on 
cultural, political and representational traditions" (Stoddart 70). Borderlands La Frontera, on the other hand, is a semi-autobiographical book imbued with elements of various fictional and non-fictional genres, such as prose, poetry, historical biography, and autobiography (Herrera and López 16), that retains elements of folk tale and magic realism that greatly define Chicana feminist perspective. Regardless of the novels' differences in temporal and social frames, this paper juxtaposes two specific literary works to demonstrate that both writers find magic realism useful in approaching their ideas.

Given that both works represent pieces of feminist literature, magic elements have a special reference to the social and gender roles of the female characters. The use of magic realism in both novels has a political implication and represents the authors' feminist response to the malecentered view of women and their treatment in patriarchal environments. To both authors, magical aspects are effective mechanisms for subverting and creating characters' alternative realities. As Bowers notes, "the characteristic of magical realism which makes it such a frequently adopted narrative mode is its inherent transgressive and subversive qualities. It is this feature that has led many postcolonial, feminist and cross-cultural writers to embrace it as a means of expressing their ideas" (63). Due to its transgressive quality, the realm of magic in both literary works can be understood in terms of Edward Soja's conceptualization of thirdspace, which is a transgressional space "radically open to additional otherness" (61). To enhance the existence of female characters beyond their subjugated positions, both writers use magical elements to create spaces of transgression as viable and less restraining environments. Regardless of the negative patriarchal views related to the female-magic relationship, both Carter and Anzaldúa subvert the particular female bonds with the supernatural or magical and present them as a symbol of feminine strength and power, because it is through magical elements that protagonists, the women in both novels, gain greater freedom, despite the patriarchal or social messages that teach otherwise.

\section{Theoretical Argumentation of Magic realism}

Many contemporary writers contend that magic realism is a literary genre, while others argue that it is a literary mode and, while opinions still vary, most critics attempt to define magic realism properly. To explain the quintessence of the genre/mode, Ann Bowers claims that "each of the versions of magic(al) realism have differing meanings for the term 'magic'; in magic realism 'magic' refers to the mystery of life: 
in marvelous and magic realism 'magic' refers to any extraordinary occurrence and particularly to anything spiritual or unaccountable by rational science" (19). The array of magical occurrences includes spirits, dead beings, supernatural, miracles, mysterious atmosphere, mythical and mystical features, exceptional abilities and all that comprises illusion and sorcery. The magical component, as further stated by Bowers, is always conveyed as real in magic realism (Ibid.).

To explain the ambivalent nature of magic realism, Stephen Slemon points out that the expression is an oxymoron itself: "the one that suggests a binary opposition between the representational code of realism and that roughly of fantasy" (409). He further argues that each opposition is "working toward the creation of a different kind of fictional world from the other" and thus neither magical nor real can completely come into being, but they remain "suspended, locked in a continuous dialectic with the other" (410). It is this dialectical relationship that creates the equilibrium of magic and reality, so that within the story neither has an absolute prevalence, but the readers remain in the space between, believing that both magic and factual are equally genuine. Hence, as Saman and Yaqoob observe: "in magic realism there is a balance between reality and the magical, they both exist at the same time and complement each other". According to these authors, magic realism "aims at showing alternative reality, not the opposite reality" (559). This partly explains why magic realism does not produce that much confusion, for we do not read a magic realist novel as, for example, we read a fantasy novel. A magic realist novel is read with a clear preunderstanding that magic elements are not in pursuit of fantasy as such, but rather, as already observed by Saman and Yaqoob, they are used to construct an alternative reality. This means that magic realism presents magical elements as real elements, whereas in fantasy fiction there is always a clear distinction between the real and unreal. In magic realism, elements of magic are recognized as part of reality itself, because they are portrayed as facts, or at least as uncommon elements of objective reality - somewhat odd and unnatural, but still undeniably apparent and present.

Exploring the influence of ambiguous magic and real dialectic on characters or narrator(s), Valerie Henitiuk underscores that magic "is not disturbing to the characters or the narrator because it is depicted as normal part of everyday reality" (410-411). Furthermore, she extends the topic beyond the character and narrator's view, underlining that even readers are not disconcerted by the supernatural, because they also accept it as real within the given fictional world (411). Evidently, Henitiuk states that magic and reality are contradicted and still tightly 
interconnected. In fact, any kind of disruption in their ambivalent, oxymoronic and yet intertwined relationship would result in the complete impossibility of magic realism as a genre.

As far as the root of magic realism is concerned, the term itself dates back to the 1920s when it was coined by the German art critic Franz Roh. Yet there are many who, influenced by the writing of Jorge Lois Borges (185-187), recognize the roots of the genre in Spanish literature, claiming that the literary precursor of magic realism was Don Quixote. Besides Cervantes, critics and writers often take Kafka's Metamorphosis as a European example of magic realism. However, the origins of the genre can also be traced in the literature of the colonizedThird World literature such as that of Latin America. In fact, many have asserted that Alejo Carpentier was the first to use the genre. Indeed, upon returning from Europe, where he became acquainted with European surrealism, Carpentier recognized the need for an artistic expression that conveys all those non-material aspects, so important for Latin American cultural history. He coined the word "realismo maravilloso"-a Latin American form of magic realism-a concept reflecting a mixture of different cultural systems and a variety of experiences that generate an incredible environment, an alternate mindset and a different appreciation of Latin America's reality (Bowers 13).

Steven Slemon argues that magic realism emerged in the Third world and postcolonial literature because the genre was most operative in cultures on the fringes of mainstream literary tradition and society, which is why it is closely linked to life on the margins (409). This may also explain why feminist texts use magic realism to present the perspectives of women who frequently inhabit margins, as they are similarly colonized by various patriarchal systems. In both feminist and post-colonial narratives, magic realism is used to destabilize imposed domination and the colonizer's version of reality, history, and truth. In an effort to explain the connection between magic realism and the postcolonial impetus, Elleke Boehmer says that postcolonial writers find ways to express their view of the world-fissured, distorted, and made incredible by cultural displacement, through magic realism (229). Moreover, another theorist Brenda Cooper argues that writers frequently use the genre as it "retains the explanatory value" and "thrives on transition, on the process of change, borders and ambiguity" (15).

The topic of magic realism also calls into question the concept of identity. As has been said, the genre is used to challenge and destabilize mainstream perceptions inherent in dominant thinking that glorifies its 
own version of the truth, history, rationality and homogenous collective identity. Back in history, the creolized people, for example, were unable to identify with colonizers because they did not fit into the prevailing definition of singular or homogenous identity. Similarly, the politics of dominance shaped female identities given that the patriarchal system awarded men with notions of totality and selfness, encouraging the creation of homogenous male identities, whereas feminine identities were reduced to that of the subordinate or the Other. Therefore, for many postcolonial and feminist writers, magic realism became a means of undermining the dominant belief in social or cultural homogeneity, providing a new space for the expression of difference and reconceptualization of self.

Obviously, both the notion of difference and conception of Otherness are reinforced by the conceptualization of magic realism itself. However, another important aspect of the genre is its transgressive nature which has popularized magic realism among various postcolonial and feminist writers, who acknowledge the capacity of magic realism to infringe on standard categorizations of truth and reality. As asserted by Bowers, "once the category of truth has been brought into question and the category of the real broken down or overturned, the boundaries of other categories become vulnerable" (64). Consequently, various dichotomies such as self and Other become critically fragile within magic realism, further opening the possibility of transposing them and the subsequent creation of alternative and modified viewpoints of self and Other. It is not unusual that many writers employ magic realism to destabilize and subvert the roles of the dominant and place more emphasis on the Other. As will be further discussed, these subversions are central to magic realism in both novels.

\section{Magic realism in Nights at the Circus}

Carter's magic realist phase began with the novel Nights at the Circus, although her earlier works, such as Magic Toyshop and The Passion of New Eve, also contained elements of magic realism. (Muždeka 50). Delivering different accounts from the extraordinary life of the main character, Nights at the Circus, coupled with Carter's later novel Wise Children, introduces elements of magic realism in the most profound manner. In Nights at the Circus, Carter confronts aspects of magic and reality through two key protagonists and lays forth the basic magic-realistic context through the magic bird-woman Fevvers and the pragmatic American journalist Walser, who interviews Fevvers, aiming 
to answer the novel's key query: "How does she do it? [...] 'Do you think she's real?'" (8-9).

At the beginning of the book, Fevvers reveals to Walser that she was hatched from an egg and describes her early life with women in the brothel, as well as her first attempt to fly. Fevver's initial confession, veiled in mysticism, raises questions about the truthfulness of her narrative and her life, both in Walser and the readers. Absorbed in Fevvers' story and intrigued by her very existence, Walser's sense of truth and reality is distorted at the beginning of the novel, and as the story progresses, he becomes deeply confused: "[...] he felt more and more like a kitten tangling up in a ball of wool it had never intended to unravel in the first place" (Carter 40). Taken up Fevvers' storytelling, he even loses time: "For the first time that night, Walser was seriously discomposed. 'Hey there! Didn't that clock strike midnight just a while ago, after the night watchman came round?" (42). As Stoddart observes, the disorienting manipulation of time is characteristic of Carter's magic realism (36). The time distortion allows Fevvers to gain greater control of the American and manipulate his sense of reality and presence. The fascinating accounts of Fevvers' life, the disruption of time, and the illusion of truth lead to increased confusion for the young American journalist, further contributing to the final decomposition of his character.

While Walser is initially endowed with superiority attributed to his maleness and American origin, his character undergoes a radical transformation towards the end of the novel. At first, he is portrayed as a typical American man from California-young, self-aware and willing to achieve his goals, but as the story progresses, readers realize that he is a naive character wanting acceptance and self-approval. As Henitiuk points out, upon hearing Fevver's story, Walser seeks comfort in his skepticism, since his entire world, perception of truth, and system of belief is threatened by magical elements which do not fit into his reasoning (413). The initial superiority, symbolically represented in Walser's Americanism and manhood, is nothing more than a guise, as his beliefs are conditioned by Fevvers' story which impels him to doubt his surrounding, truth, and even self. Thus, despite being unusual and different, Fevvers soon assumes the dominant position. She achieves this with her storytelling. She recounts the supernatural aspects of her being, talks about her wings and accepts the abnormality and her bodily difference as "an irreconcilable division between myself and humankind" (Carter 34). However, she also claims that she and people like her are as real as Walser himself: "with hearts that beat like yours [Walser's]" (69). To Fevvers, magic and storytelling become a strategy 
to take control not just of the story, but also of Walser and the entire perception of reality.

The part of the book, when Fevvers enters the museum of monsters, a place where everybody is like her-unnatural, hybrid, and monstrous - further intensifies the magical expression of the novel. In a Gothic setting, we encounter a living skeleton Mrs. Schreck who runs the museum, her mouthless servant Toussaint, Sleeping Beauty who only wakes up to eat, transsexual Albert/Albertina, a dwarf girl named Wonder and Fanny with her eyes on her nipples. According to Fevvers, her friends are very lonely souls; their lives are filled with misery as they are controlled by a cold-hearted woman, but that is the only place they fit in, as Fanny concludes: "Amongst the monsters, I am well hidden; who looks for a leaf in the forest?" (Carter 65). Even though the monstrous residents of the museum are different from what is generally regarded as ordinary and normal, they are all real. Similar to Fevvers, these characters are also shrouded in a veil of magic and illusion, further intensifying mysticism in the novel and challenging the conventional perception of the ordinary and unnatural, true and imaginary. For example, in recounting the story of the mute Toussaint, Fevvers reveals that before becoming Schreck's servant, he used to work at fairs where people poked and pried at him. She notes that such behavior has made these people look unnatural, not the mute Toussaint. At this point in the book, Fevvers raises the central question of magic realism: "For what is natural or unnatural, sir?", and continues:" The mold in which human form is cast is exceedingly fragile" (Carter 61). By this, Fevvers suggests that one cannot, with utter certainty, say that one thing is natural or genuine and the other is not.

The second part of the novel recounts the episodes in Colonel Kearney's circus in St. Petersburg. This section illustrates an interesting juxtaposition of human and animal behavior. Colonel Kearney assumes that his pig Sybil has divine abilities. He runs his business by consulting with the pig, and the entire circus depends on the Sybil, who predicts the future, spells words, and acts like a human. Presenting an animal as a human-like creature underscores Carter's aim to further debase traditional perceptions and reasoning by blurring the line between reality and fantasy. At the end of this part of the book, we come across another significant magical occurrence. It is when Fevvers, in an effort to flee from the Grand Duke, hops on the model train that unexpectedly becomes a real train running through the taigas of the great Siberia. The jump, as Abdullah states, "blurs the concept of immovable space and creates a break between reality and fantasy therefore contributing to the element of the supernatural" (14). 
The third part of the novel previews the circus ensemble traveling through Siberia. The train is soon attacked by a group of outlaws and it explodes. Following the explosion, all circus members, except Walser, are taken hostage by the outlaws. Fortunately, Walser is saved by a group of female assassins who had fled the house of correction run by Countess P. However, after the train incident, Walser completely loses his mind and takes on animalistic behavior. The erasure of Walser's memory and his transformation into a human chicken represents the destruction of the Western viewpoint expressed in his character. Hence, by the end of the novel, Walser becomes more like Fevvers-a transgressive character or a hybrid, inadequate to all those who prey on rational ontological explanations. By turning into a chicken, Walser is not only dehumanized but, more importantly, de-masculinized. Paradoxically, these erasures impel a remarkable rebirth of his character, allowing him to step beyond the initial pragmatism, as his mind is finally liberated from the constructs embedded in Western thought:

"Walser flutters across the snowy wastes. He is a sentient being, still, but no longer the rational one [...] now he is all sensibility without a grain of sense [...] In this elevated state, he harkens to the rhythm of the drum" (Carter 236).

In addition to accounts of various magical occurrences, the magic realist atmosphere in the novel is augmented by a profusion of narrative details. Although the Baroque narrative may often disorientate readers, it is intentionally used to stimulate the perception of the extraordinary and magical. In addition to textual abundance, Carter uses an unreliable narrator as a distinctive characteristic of her magic realist texts. As Hegerfeldt points out, unreliable narrators in magic realism are used to generate ambiguity (101). At the end of The Nights at the Circus, narrator Fevvers says: "To think I really fooled you! She marveled. It just goes to show there's nothing like confidence" (Carter 295). Hence, not only are readers told that Fevvers' accounts may be inaccurate, but they are invited to reassess everything they had read. The attempt to discredit the narrator serves to lead readers back to the beginning and initial question of what is real and true. Therefore, as might be expected, the novel finishes where it starts-in London, with Fevvers requiring Walser to start writing the story anew: "That's the way to start the interview [...] Get out your pencil and we'll begin!" (Carter 291). 


\subsection{Magic in Carter's Feminist Rhetoric}

As has already been argued, magic realist texts are subversive given that "their in-betweenness, their all-at-onceness encourages resistance to monological political and cultural structures, a feature that has made the mode particularly useful to writers in postcolonial cultures and, increasingly, to women" (Zamora and Faris 6). In Nights at the Circus, magic realism endorses Carter's feminist criticism and seeks to deconstruct prevailing patriarchal narratives. In the case of Fevvers, elements of magic and reality are juxtaposed to convey Carter's feminist ideas. Hence, it is through magic realism that Carter creates a feminist space of resistance. Contrary to Fevvers, who juggles life between reality and magic to preserve sanity, the pragmatic and powerful Walser loses his mind by the end of the book and his reality is shattered in the novel. Furthermore, the dualistic nature of magic realism conveys fundamental dichotomies: self and other, male and female, presence and absence, all of which have become topical in feminist discussions. As said before, the idea of otherness is expressed in both magic realism and feminist narratives. In Carter's novel, hybrid characters thrive on difference that contradicts dominant beliefs and values. Half-woman and half-bird Fevvers is the embodiment of otherness, because her physical appearance deviates from what is considered natural. Additionally, the fact that she is a woman puts her on the double margins of Western patriarchal culture.

Fevvers' otherness is not only expressed in her different and magical appearance, but also spatially conveyed, as she inhabits marginal spaces: the brothel, the monsters' museum, the circus-spaces on the margins in which deviants reside. As identified by French philosopher Michel Foucault in his seminal work "Of Other Spaces", these are heterotopic spaces. In contrast to utopias, heterotopias are highly complex, discursive environments that both reflect and contradict common spaces, demonstrating a radical openness to difference. Foucault uses graves, brothels, prisons, mental hospitals, and other institutions to illustrate the most common heterotopias, arguing that each has "precise and well-defined function within society and the same heterotopia can, in accordance with the synchronicity of the culture in which it is located, have a different function" (333). The primary function of spaces occupied by Fevvers and her friends is to divide and isolate them from the mainstream culture that expels them due to their deviances. Furthermore, reflecting Soja's conceptualization of thirdspace, which transcends traditional binary logic by sublimating "abstract and concrete, real and imagined, knowable and unimaginable, 
structure and agency, mind and body, consciousness and unconsciousness, everyday life and unending history" (56-57), the spaces in the novel have a transgressive function that facilitates the subversion of dominant viewpoints, ideologies, and assumptions. In this regard, the use of magical realism in the novel contributes to the formation of a specific environment, the thirdspace, which provides conditions for transcending established hegemonic systems, such as patriarchy. As Henitiuk points out "patriarchal worlds, fictional or otherwise, typically employ rigid sex roles and masculine hegemony to deny women's mastery over the three dimensions of space, and thus Fevvers looks beyond the spatial with a view to attaining autonomy" (421).

At the beginning of the novel, Fevvers is contrasted to the pragmatic American man whose ambition is to write a story about this enigmatic woman. The beginning of the book centralizes opposite characters-a hybrid and magical woman Fevvers with no specific occupation or aim, and Walser-the embodiment of patriarchal male authority. Equipped with the power of the pen, it seems that Walser has authority and control at the beginning of the novel. He presents a threat to Fevvers, given that his writing may either destroy or give rise to Fevvers' popularity. In other words, Walser has the opportunity to create the image of Fevvers as he pleases. Henitiuk points out that he is there to assign Fevvers "a (false) identity, as humbug, whore and/or freak of nature [...] to write her story, to textualize her" (414). Walser's initial goal is to debunk Fevvers' powers and portray her as a fraud, so he devotes himself to materializing Fevvers in a way that conforms to Western society's logic. However, as we learn later, Fevvers takes advantage of her uniqueness and difference, transforming them into a source of power and strength. Therefore, elements of magic realism that surround Fevver's character become a means to achieve feminist aims and subvert male authority. Fevvers' strategy is simple: confuse the opponent and persuade him to rethink what he thought he understood. By confusing and distracting Walser, either by strange appearance or deceptive narration, Fevvers manipulates masculine authority embodied in Walser and thus refusing to comply with autocratic masculine principles. In doing so, she takes control of everything: Walser, the story, and the readers.

Although Fevvers speaks from the margins, she shows a great deal of independence because she does not need any provision from others. Moreover, she earns money for others-Madam Schreck and the Colonel, but more importantly, she does not have to work as a prostitute because her uniqueness raises enough interest and curiosity in people 
that she can make a living by simply exhibiting herself. This is how Carter alters Fevvers' abnormality and bridges the aspects of magical with independence and control. Such power, as Saman and Yaqoob point out, allows female characters like Fevvers to "enact their selves subversively" (564). Similar tactics of patriarchal subversion are commonly accepted by many contemporary feminist authors and recognized as a potential course of action for oppressed women. In Nights at the Circus, both the character of Fevvers and the strategies of magic realism are used to devalue the prevailing social and patriarchal ideologies in which women are assigned inferior social positions. In the book, Carter uses the antinomy found in magic realism to expose the paradoxical nature of patriarchal male-centered thought and underscore the significance of subversive feminist action.

Fevvers' monstrosity has a number of other feminist implications. As Hanaitiuk points out, a free woman in an unfree society will always be seen as a monster (423). Carter's heroine uses monstrosity to break with the social and patriarchal constraints imposed on her and other women. For that reason, as Henitiuk further observes, Fevvers:

"is constantly evading those who would possess/contain/define her. To this end, she posits an alternate version of reality with her corporeal self and a 'fluid identity that destabilizes the rigid boundary between the subject and object' [...] Carter's heroine acts as an explicit reference to the othering of women as freaks of nature, figures of deviance, and turns these damaging perceptions on their head" (419).

The magical aspect of Fevvers' corporeal self, the wings, becomes an epitome of her freedom. Obviously, the wings have an intrinsic value in her life, which she confirms when one of them is broken: "I suspect that not only my wing, but also my heart has been a little broken" (Carter 234). Fevvers understands how important her wings are to her survival. In fact, it is through this magical element of her body, the hybridity, that she establishes her identity.

Hence, by informing the story with magical elements, Carter equips her female character with a chance to survive. Hybridity embedded in Fevvers opens up the possibility of female alteration and repositioning. It is through the juxtaposition of magic and realism that Carter creates space for women like Fevvers. This new space is free from the prevailing assumptions, particularly those relating to gender. However, Carters' feminist course in Nights at the Circus goes beyond the simplistic subversion of male and female roles as she also scratches the surface of transgender issues. As pointed out by Paulina 
Palmer, many writers employ elements of magic realism to explore the various types of transgender (15). Although this intention is not openly expressed in Carters' novel, at one point the readers are confronted with Walser's suspicion that Fevvers is, in fact, a male: "It flickered through his mind: Is she really a man?" (Carter 35). This adds to the overall impression that Carter's Nights at the Circus not only delineates the psychological dimension of characters, but shifts the focus to their physical manifestations, opening up other genderrelated issues. At the end of the novel, Fevvers demonstrates a complete feminine authority. Her ironic narrative tone, as well as her carnivalesque laugh that magically reverberates across the entire planet, underpins a newly conceived realization that she has fully established herself and her dominance.

\section{Borderlands La Frontera: Myth and Reality}

Although it has been more than three decades since the publication of Anzaldúa's Borderlands La Frontera, the book continues to draw attention, retaining the highest relevance in Chicana literary and cultural studies. To Anzaldúa, borderlands not only represent a distinctive physical space-a border between Latin America and the U.S., but it entails specific cognitive and spiritual state, becoming the central "miscegenation metaphor" (Herrera and López 13). As a metaphor of divided cultural reality and identity, it emerges from the junction of different and opposing cultural systems - the U.S. and Latin American. Thus, as in magical realism, Anzaldúa's borderlands integrate oxymoronic paradigms that illuminate hybridity and transgression.

The book Borderlands La Frontera derives its content from Anzaldúa's experience of a Chicana and a lesbian. It promotes both feminist and queer ideas, as the author ventures to deconstruct standard male-centered perspectives, offering a peculiar cultural and feminist re-writing of Chicanas' position in the U.S. As Garcia notes, Anzaldúa "combines history, myth, spirituality, sexuality, and politics to map out a new direction for all people in general and women in particular" (38). Moreover, she indulges in creating a system more favorable to Chicanas and does this by recounting personal experiences on the Mexican-American border. By incorporating cultural references and elements from Indian mythology, she explores the poetics of borderlands "as a space of radical openness and a Thirdspace filled with perils and possibilities" (Soja 127), thus creating new feminist perspectives on Chicana life. 
Building on the reality of the border, Anzaldúa embraces the mythological and spiritual aspects of Mesoamerican culture to validate the ambiguity and liminality as innate features of both the borderlands and the magic realism embodied in her work. The transposition of magic realist associations to the conception of borderlands indicates that these two aspects function in a similar way. Both share a transgressional capacity that opposes valorization of singularity and homogeneity embedded in Western thought, encouraging the new modes of thinking about hybridity, difference and ambiguity. Borderland, as Anzaldúa notes, is in a "constant state of transition" (25). Such fluidity, which allows for the duality and cultural hybridity of Latino/a people, is not only central to Anzaldúa's concept of borderlands, but her use of magic realism as well. Because of the specific ties with Latino culture and tradition, Anzaldúa's work can be classified as Ontological Magic Realism that "has as its source material beliefs or practices from the cultural context in which the text is set" (Bowers 86).

In the first chapter, Anzaldúa presents the idea of the supernatural as a vital part of Latino culture. Claiming that the supernatural has a primordial connotation, she asserts that "humans fear the supernatural, both the un-divine (the animal impulses such as sexuality, the unconscious, the unknown, the alien) and the divine (the superhuman, the god in us)" (39) and proceeds to clarify that most cultures see women as closely connected to the fearful un-divine realm: "woman is carnal, animal and closer to the undivine, she must be protected. Protected from herself. Woman is the stranger, the other. She is man's recognized nightmarish pieces, his Shadow-Beast" (Ibid). Evidently, Anzaldúa makes a plausible connection between women and supernatural or magical, arguing that women are men's Shadow-Beasts. Thus, she highlights the demonized and inhuman view of women in patriarchy. However, while the reference to the supernatural is usually seen as negative and has put many pressures on women's backs, nonetheless, it is a tremendous source of strength and power for Anzaldúa. In her book, she combines numerous mythical figures and traditional folk tales, usually involving supernatural beings or instances, with elements of reality to create a new space for all Chicanas. In recreating mythical female figures and invoking magic elements, Anzaldúa demonstrates that the bond between women and the supernatural can become an advantage. Hence, she does not dispute the link between women, magical and mysterious, but uses the relation to promote Latinas' positions. 
Besides feminist ideology, elements of magic realism in Borderlands La Frontera serve to articulate acute problems in ethnic minorities, specifically Chicanas harboring a borderland consciousness. As pointed out in the theoretical framework, magic realism is used to destabilize the radical views of the power elite and Anzaldúa uses it to validate hybridity and ambiguity of Latino minorities. Since magic realism offers space to re-assess and reconceptualize socially established meanings such as identity and selfother relationship, she employs elements from Indian mythology to pose questions about the Chicana identity. These elements help to authenticate the simultaneity embedded in the Chicana conception of self. As Henriques observes, Anzaldúa re-appropriates ancient representations of goddesses and superhuman beings in order to deliver new and powerful modes of thinking (42). Thus, Anzaldúa creates new Chicana narratives and consciousness "by creating a new mythos - that is a change in the way we perceive reality, the way we see ourselves, and the ways we behave" (102). For Anzaldúa, hybrid identity is not only a matter of the conscious self, but also a matter of all that remains hidden underneath-the irrational, mystical and magical. In her book, she accepts all the underlying aspects of her consciousness as the core of her being: "I have always been aware that there is a greater power than the conscious $I$. That power is my inner self, the entity that is the total sum of all my reincarnations, the godwoman in me I call Antigua, mi Diosa, the divine within" (72). By describing herself as the sum of reincarnations, Anzaldúa draws attention to the supernatural and mythical aspects that are important to her immediate existence and divided cultural reality. While celebrating the subconscious as an important part of Chicana reality, culture and identity, Anzaldúa develops what she terms the new mestiza, a Chicana with a specific borderline consciousness:

"la mestiza is the product of the transfer of the cultural and spiritual values of one group to another [...] The new mestiza copes by developing a tolerance for contradictions, a tolerance for ambiguity [...] She learns to juggle cultures. She has a plural personality, she operates in pluralistic mode - nothing is thrust on, the good the bad and the ugly, nothing rejected, nothing abandoned. Not only that she sustains contradictions, she turns the ambivalence into something else" (100-101).

Obviously, the contemporary mestiza, or a woman of a mixed breed, is presented as a female force that defies all cultural or gender contradictions. Anzaldúa invokes a magic-like image of the new mestiza 
because she sustains the vagueness of Chicana's experience. It should not be forgotten, however, that mestiza is not just an artificial or theoretical construct, as each represents a real person-a miracle embedded in the present, a magic realism itself. She is a living person, a woman who accepts the disparity, the complexity, mixed ethnicity and the diversity as genuine parts of her being. Such a woman is at the same time extraordinary and magical, but nevertheless real.

\subsection{Subversion of Traditional Mythology: La Llorona and}

\section{Coatlique}

Anzaldúa creates the new mestiza on the tenants of ancient Mexican mythology. In her work, she re-introduces the myth of La Llorona, a wailing woman, to provide empowerment to other Chicanas, as well as to all those who, as Anzaldúa says, are considered "subhuman, inhuman, non-human" (40). According to Mexican folk tradition, La Llorona drowned her children and committed suicide as an act of revenge against abandonment by her husband. While the wailing woman La Llorona traditionally invokes negative associations in Latino culture, Anzaldúa uses her image to promote feminist ideas. As she claims, La Llorona's wailing represents a sign of resistance and is a protest against any social and cultural change that had exerted an effect on ancient Indian women and, consequently, on all Chicanas:

"My Chicana identity is grounded in the Indian woman's history of resistance. The Aztec female rites of mourning were rites of defiance protesting the cultural changes which disrupted the equality and balance between female and male, and protesting their demotion to a lesser status, their denigration. Like La Llorona, the Indian woman's only means of protest was wailing" (Anzaldúa 43).

Hence, the use of La Llorona's myth is seen as a critique of both past colonial behavior and contemporary patriarchal culture in which Latino women protest in a similar manner against the culturally dominant and male-centered views. Therefore, the invocation of this myth helps Anzaldúa not only to bind the past and present, but to reconstruct reality, given that ghosts like La Llorona offer "alternative stories that challenge the dominant history" (Watanabe 105).

Besides recalling La Llorona, Anzaldúa invokes the pre-Hispanic goddess Coatlicue, the goddess of fertility and earth. Endowed with powers to create and destroy, Coatlicue is an ambivalent figure that renders hybridism and a divided Chicana consciousness. In contrast to 
the commonly invoked image of La Virgen in Chicana literature, Coatlicue is a symbol of empowerment and an embodiment of duality; she is an "entity in which opposites reside, in which conflict and resolution are encompassed within her nature" (Sobek 26). Coatlicue's dualism is reflected in her appearance: she is wearing a skirt of interwoven snakes and a necklace made of human hearts, hands and sculls. Her feet and hands are claws and her breasts are flabby from nursing. Both magical and real come together in Anzaldúa's rewriting of Coatlicue, as she re-appropriates and merges this indigenous female image with Chicanas' reality on the border. In this way, she creates a magic realist framework that supports ambivalence, dualism and opposition inherent in the life of each Chicana.

The fascination of Chicana writers with Coatlicue comes from the recognition of Coatlicue's ability and power, as she takes part in the processes of creation and destruction. The supernatural elements inherent in her image create a sense of invincibility. In the eyes of feminists like Anzaldúa, Coatlicue is an active female force and identification with her helps Chicanas accept and validate their own ambivalences. Hence, this figure also represents an apt role model for Anzaldúa's new mestizas who "interpret history and, using new symbols, shape new myths" (104), thus becoming more like Coatlicue-magical, strong, and invincible.

Coatlicue and other representations of the Mesoamerican folk culture in Anzaldúa's book serve to point to the simultaneity of self. Troubled by hybridism, Anzaldúa invokes these female figures to reinvent the many selves within her. As Tamdgidi observes, this way she seeks a "way out of the habituated ways of being, thinking, and feeling" (276). The departure from the conventional modes of thinking helps the Chicanas to reconnect with the past, and bridge the conscious self, their immediate realities, with their inner and spiritual selves in order to reach totality. As Anzaldúa argues, each Chicana thus "becomes a nauhual $^{13}$, able to transform herself into a tree, a coyote, into another person. She learns to transform the small 'I' into the total Self" (82-83). Acquiring superhuman power to transform, Anzaldúa manages to bridge oppositions embedded in her original culture and Western society, linking her traditional inheritance with contemporary reality and living on the border.

To further promote concepts related to Chicanas' cultural hybridism, besides the reproduction of mythical figures, Anzaldúa also

13 Nahual derives from the Mesoamerican folk culture and represents a human being endowed with the power to turn into animals. 
points to the other side-the realm of ghosts. Similar to Carter's use of magic realism, Anzaldúa internalizes the elements of supernatural to criticize Western self-confidence and rationality:

"Like many Indians and Mexicans, I did not deem my psychic experiences real... I allowed white rationality to tell me that the existence of "other world" was mere pagan superstition. I accepted their reality, the "official reality" of the rational, reasoning mode which is connected with external reality, the upper world, and is considered the most developed consciousness - the consciousness of duality" (58-59).

The passage above illustrates how Western authority has denied relevant aspects of Latino cultural tradition. While Anzaldúa claims that Western rationality is commonly perceived as a higher state of thought and consciousness that rejects the presence of the other world, she maintains that those who consider the supernatural as a part of reality continue to fascinate the members of Western culture: "They are fascinated by what they call the 'magical mind', the 'savage' mind, the participatio mystique of the mind that says the world of the imagination, world of the soul and spirit, is just as real as physical reality" (59). In contrast to Western civilization, Anzaldúa embraces the mystical aspects of Latino heritage, as she sees them inseparable from her tradition, community and reality:

"Voodoo, Santeria, Shamanism and other native religions are called cults and their beliefs are called mythologies. In my own life, the Catholic Church fails to give meaning to my daily acts, to my continuing encounters with the 'other world' [...] No matter to what use my people put the supernatural world, it is evident to me now that the spirit world, whose existence whites are so adamant in denying, does in fact exist. This very minute I sense the presence of my ancestors in my room" (59-60).

Evidently, Anzaldúa acknowledges the existence of the supernatural as part of the reality and immediate existence of Latino/a people. By claiming that her own experience involves sensations of inhuman existence, i.e., the spirits of her ancestors, she establishes herself as a witness to supernatural presences. She thus gives more legitimacy to this aspect of Latino tradition, but also to her own life, and to all her fellow people who inhabit two realities and live between two cognitive grounds. Hence, in Borderlands La Frontera she intentionally employs supernatural elements, creating a magic realist atmosphere, as 
she believes these elements must be kept as integral parts of border reality and identification of Latino people.

\section{Conclusion}

Elements of magic realism in Angela Carter's Nights in the Circus and supernatural and mythical elements in Gloria Anzaldúa's Borderlands La Frontera expose acute socio-cultural and female issues in British and U.S. societies. The paper shows that writers utilize various magical elements to explore and provide alternatives for all those outside the definition of the prevailing or dominant. Using aspects of magic realism, Carter and Anzaldúa create alternative realities and offer them to people on the social margins-women and ethnic minorities. In the process of presenting supernatural aspects as part of physical and factual reality, writers develop a unique strategy of social and gender subversion. Through the reproduction of myth and the supernatural, they unveil the deeply troubling issue of supremacy and subvert the dominance embodied in both Western culture and male-centered narratives. As argued in the paper, both authors use magic elements to solve disputed questions of personal and social representation, as well as the identity of the non-dominant.

\section{Works Cited:}

Abdullah, Zainab. "Magic realism in Angela Carter's Novel Nights at the Circus". Journal of Al-Ferhedis Arts, 2013: 2-35. IRAQUI Academic Scientific Journal. Web. 21. Avg. 2019.

Anzaldúa, Gloria E. Borderlands La Frontera: The New Mestiza. San Francisco: Aunt Lute Books, 1999. Print.

Boehmer, Elleke. Colonial and Postcolonial Literature. 2nd ed. Oxford: Oxford U $P, 2005$. Print.

Borges, Jorge L. "Partial Magic in the Quixote". Labyrinths: Selected Stories and Other Writings. Ed. Donald A. Yates and James E. Irby. New York: New Direction P, 1964. 185-187. Print.

Bowers, Maggie Ann. Magic(al) Realism. London: Routledge, 2004. Print.

Carter, Angela. Nights at the Circus. London: Picador, 1985. Print.

Cooper, Brenda. Magic realism in West African Fiction. London: Routledge, 2004. Print.

Foucault, Michel. "Of Other Spaces: Utopias and Heterotopias". Rethinking Architecture: A Reader in Cultural Theory. Ed. Neil Leach. NYC: Routledge, 1997. 329-336. Print.

Garcia, Richard A. "Toward a Theory of Latina Rebirth - Renacimiento de la Tierra Madre: The Feminism of Gloria Anzaldua", Race, Gender and Class. January 1997: 29-44. Web. 12 July 2021. 
Hegerfeldt, Ann C. Lies that Tell the Truth: Magic Realism seen through Contemporary Fiction from Britain. Amsterdam: Rodopi, 2005. Print.

Henitiuk, Valerie. "Step into my Parlour: Magic realism and the Creation of Feminist Space", Canadian Review of Comparative Literature. 5 September 2019: 410-427. Web. 2 Oct. 2020.

Henriquez-Batanor, María. “Anzaldúa and 'the new mestiza': A Chicana dives into collective identity". Language Value. December 2012: 38-55. Web. 12 Mar 2020.

Herrera, Cristina, and Larissa M. Mercado-López. (Re)Mapping the Latina/o Literary Landscape: New Works and New Directions. Fresno: Palgrave Macmillan, 2016. Print.

Mudžeka, Nina. "Alchemical Cities, Apocalyptic Cities: The City as an Exponent of Magic realism and Ideology in Angela Carter's Novels". SCIENDO. 1 June 2020: 49-68. Web. 20 Feb. 2021.

Palmer, Paulina. Queering Contemporary Gothic Narratives 1970-2012. London: Palgrave Gothic, 2016. Print.

Saman, Attia and Munazza Yaqoob. "Constructing the feminist identity, subversion and divisiveness: some insights of literature". Academic Research Journal 4.3. (2013): 559-566. Print.

Slemon, Stephen. "Magic realism as Postcolonial Discourse". Magic realism: Theory, History, Community. Ed. Lois P. Zamora and Wendy B. Faris. Durham: Duke U P, 1995. 407-427. Print.

Soja, Edward W. Thirdspace. Malden: Blackwell, 1996. Print.

Stoddart, Helen. Angela Carter's Night at the Circus. London: Routledge, 2007. Print.

Tamdgidi, Mohammed H. "Anzaldúa's Sociological Imagination-Comparative Applied Insights into Utopistic and Quantal Sociology". Human Architecture: Journal of the Sociology of Self-Knowledge. 4 (2006): 265286. Print.

Watanabe, Asami. "Living Sin Fronteras: Transforming Body and Ethnic Mythologization in Gloria Anzaldúa's Works". Bulletin of Sapporo U Women's College. Mar. 2013: 95-123. CORE. Web. 4. Feb. 2020.

Zamora, Lois P. and Wendy B. Faris. Magic realism: Theory, History, Community. Durham: Duke U P, 1995. Print.

\section{EL VIAJE HACIA SOBRENATURAL: LOS ELEMENTOS DEL REALISMO MÁGICO EN LAS NOVELAS NOCHE EN EL CIRCO DE ANGELA CARTER Y BORDERLANDS LA FRONTERA: THE NEW MESTIZA DE GLORIA E. ANSALDUA}

Esta obra se centra en los elementos del realismo mágico en las novelas Noches en el Circo de Angela Carter y Borderlands La Frontera: The New Mestiza de Gloria E. Anzaldúa. Aunque estas dos novelas pertenecen a diferentes períodos de tiempo y cánones literarios las escritoras utilizan los elementos míticos y sobrenaturales para los propósitos similares-para desafiar las opiniones de la 
sociedad británica y estadounidense. Al incorporar los elementos mágicos en sus obras, las escritoras examinan los valores patriarcales y occidentales para justificar y validar identidades basadas en las hibridaciones y las diferencias.

Palabras clave: Realismo mágico, realidad, sobrenatural, mito, género, cultura, hibridación, Carter, Anzaldúa. 